\title{
PENERAPAN TEORI MULTIPLE INTELLIGENCES DALAM PEMBELAJARAN FISIKA UNTUK MENINGKATKAN HASIL BELAJAR PESERTA DIDIK
}

\author{
Dewi Sartika \\ Jurusan Pendidikan Fisika - FMIPA Universitas Sulawesi Barat; \\ e-mail: dewisartika.asrulbatiran@yahoo.co.id
}

\begin{abstract}
Abstrak
Penelitian ini merupakan penelitian pra eksperimen yang bertujuan untuk mengetahui peningkatan hasil belajar peserta didik melalui Penerapan Teori Multiple Intelligences dalam pembelajaran fisika. Penelitian ini dianggap penting karena setiap peserta didik pada dasarnya memiliki intelegensi dominan yang berbeda-beda. Sehingga kemampuan menangkap pelajaranpun akan berbeda-beda pula. Hal inilah yang secara tidak langsung mempengaruhi rendahnya hasil belajar fisika peserta didik. Untuk mengetahui seberapa besar peningkatan hasil belajar fisika peserta didik dengan diterapkannya teori multiple intelligences dalam pembelajaran, maka digunakan One Group Pre Test-Post Test Design sebagai desain penelitian, dimana dilakukan tes sebelum (pretest) dan setelah (posttest) pembelajaran. Dari hasil analisis menunjukkan bahwa terdapat peningkatan hasil belajar yang signifikan pada kelas yang diajar dengan penerapan teori multiple intelligences. Sehingga dapat dikatakan bahwa pendekatan pembelajaran berbasis multiple intelligences dapat digunakan dalam proses pembelajaran untuk meningkatkan hasil belajar fisika peserta didik. Olehnya itu sangat penting bagi para pengajar fisika untuk menerapkan suatu teknik mengajar yang sesuai dengan kecerdasan dominan para peserta didiknya dan kecerdasan dominan pengajar itu sendiri.
\end{abstract}

Kata kunci-Multiple intelligences, Hasil Belajar, One Group Pre Test-Post Test Design

\section{PENDAHULUAN}

Fisika merupakan salah satu mata pelajaran sains yang menjadikan kemampuan pemahaman konsep sebagai syarat mutlak dalam mencapai keberhasilan belajarnya. Hanya dengan penguasaan konsep fisika seluruh permasalahan fisika dapat dipecahkan, baik permasalahan fisika yang ada dalam kehidupan sehari-hari maupun permasalahan fisika dalam bentuk soal-soal fisika di sekolah. Hal ini menunjukkan bahwa pelajaran fisika bukanlah pelajaran hafalan tetapi lebih menuntut pemahaman konsep bahkan aplikasi konsep tersebut.

Sejak dulu hingga saat ini kebanyakan peserta didik memiliki ketertarikan yang kurang terhadap mata pelajaran Fisika, bahkan tidak sedikit dari mereka malah merasa "takut" terhadap mata pelajaran ini. Kecenderungan ini biasanya berawal dari pengalaman belajar mereka, dimana mereka menemukan kenyataan bahwa pelajaran fisika adalah pelajaran 'berat' dan serius yang tidak jauh dari persoalan konsep, pemahaman konsep, penyelesaian soal-soal yang rumit melalui pendekatan matematis hingga kegiatan praktikum yang menuntut mereka melakukan segala sesuatunya dengan sangat teliti. Akibatnya tujuan pembelajaran yang diharapkan, menjadi sulit dicapai.

Mata pelajaran fisika juga menjadi momok bagi para peserta didik karena hubungannya erat dengan matematika. Kemampuan matematis peserta didik yang lemah secara otomatis akan mengalami kesulitan dalam memahami fisika, karena sebagian besar penyelesaian soal-soal fisika dilakukan melalui pendekatan secara matematis. Artinya, peserta didik yang memiliki kecerdasan dalam bidang angka atau logika (Logical-Mathematical Intelligence) saja yang dapat memahami pelajaran fisika dengan baik. Padahal tidak semua peserta didik memiliki kemampuan yang cukup dalam bidang matematika.

Menurut T. Amstrong (dalam Uno, 2009) dalam bukunya "Kamu Itu Lebih Cerdas Daripada Yang Kamu Duga" (You're Smarter Than You Think), anak-anak memiliki Multiple Intelligences. Dalam buku tersebut dikatakan sedikitnya ada 8 macam kecerdasan yang salah satu atau beberapa diantaranya dapat dimiliki oleh seorang anak, yaitu:

1. Kecerdasan dalam menggunakan kata-kata (Linguistic Intelligence)

2. Kecerdasan dalam bermusik (Musical Intelligence)

3. Kecerdasan dalam menggunakan logika (Logical-Mathematical Intelligence) 
4. Kecerdasan dalam menggunakan gambar (Visual-Spatial Intelligence)

5. Kecerdasan dalam memahami tubuh (Bodily-Kinesthetic Intelligence)

6. Kecerdasan dalam memahami sesama (Interpersonal Intelligence)

7. Kecerdasan dalam memahami diri sendiri (Intrapersonal Intelligence)

8. Kecerdasan dalam memahami alam (Naturalist Intelligence)

Berdasarkan hasil observasi penulis di beberapa sekolah di wilayah Makassar, sekolah-sekolah tersebut pada dasarnya memiliki peserta didik yang mempunyai karakteristik yang berbeda. Keragaman individu ini diantaranya dilihat dari intelegensi. Perbedaan intelegensi ini sangat nampak terutama dalam mata pelajaran fisika. Sebagian peserta didik menganggap fisika adalah pelajaran yang sangat rumit, yang sangat identik dengan berbagai rumus. Namun tidak semua peserta didik berfikir demikian, bagi peserta didik yang berintelegensi kuat dalam hal matematis atau hitunghitungan, fisika adalah sebuah mata pelajaran yang menyenangkan. Hal ini senada dengan hasil penelitian Piping Sugiharti dalam jurnalnya mengenai pembelajaran berbasis multiple intelligences.

Ketidak-tertarikan peserta didik terhadap suatu pelajaran, tidak akan menumbuhkan motivasi diri untuk mempelajari apapun tentang pelajaran tersebut. Hal inilah yang secara tidak langsung menjadi salah satu penyebab tidak tercapainya tujuan pembelajaran yang kemudian berimbas terhadap rendahnya nilai rata-rata fisika peserta didik SMA Neg. 3 Makassar yang ditunjukkan oleh data berikut : XI IPA 1 =75,63; XI IPA 2 = 64,70; XI IPA 3 = 57,46; XI IPA 4 = 54,23; XI IPA $5=$ 52,62 ; XI IPA $6=51,73$. Sedang Multiple Intelligences menyarankan kepada kita untuk mempromosikan kemampuan atau kelebihan seorang anak dan mengubur ketidakmampuan atau kelemahan anak. Proses menemukan inilah yang menjadi sumber kecerdasan seorang anak (Munif, 2010).

Oleh karena itu diperlukan sebuah pendekatan pembelajaran yang memungkinkan peserta didik dapat memahami pelajaran fisika. Dan salah satu diantara pendekatan yang dapat digunakan yaitu pendekatan pembelajaran fisika yang didasarkan pada keragaman kecerdasan (Multiple Intelligences).

Menurut Piping Sugiharti (2005) kelebihan dari model pembelajaran ini yaitu :

1. Aktivitas pengajaran yang disesuaikan dengan ragam kecerdasan yang dimiliki oleh peserta didik sedikit banyak telah memunculkan semangat belajar dan rasa percaya diri pada setiap peserta didik.

2. Melalui penerapan teori Multiple Intelligences dalam pembelajaran fisika telah menggugurkan anggapan bahwa pelajaran fisika itu sulit dan tidak menyenangkan.

3. Melalui teori Multiple Intelligences ini pula peserta didik belajar untuk lebih menggali potensi yang ada pada dirinya dan dapat lebih menghargai talenta yang telah dianugerahkan Tuhan kepadanya. Selain itu peserta didik juga belajar untuk menghargai kelebihan dan kekurangan masing-masing.

Dari ulasan di atas dapat dimengerti bahwa dalam mengimplementasikan pendekatan pembelajaran berbasis teori Multiple Intelligences, masalah mendasar yang perlu diperhatikan yaitu masalah mengidentifikasi jenis kecerdasan dominan bagi masing-masing peserta didik serta mendesain metode pembelajaran yang sesuai dengan masing-masing karakteristik intelegensinya.

\subsection{Kerangka Penelitian}

\section{METODE PENELITIAN}

Dalam menerapkan teori Multiple Intellegences, digunakan beberapa teknik-teknik mengajar yang disesuaikan dengan karakteristik peserta didik dalam mengikuti pembelajaran. Pengajar terlebih dahulu mengetahui jenis kecerdasan dominan guru, kemudian mengetahui jenis-jenis kecerdasan dominan yang dimiliki oleh peserta didik, setelah itu peserta didik dibagi kedalam beberapa kelompok berdasarkan kecerdasan dominannya masing-masing. Setiap kelompok diberikan kebebasan untuk menuangkan ide-idenya sesuai kecerdasan dominanan yang mereka miliki masing-masing. Secara singkat dapat digambarkan sebagai berikut : 


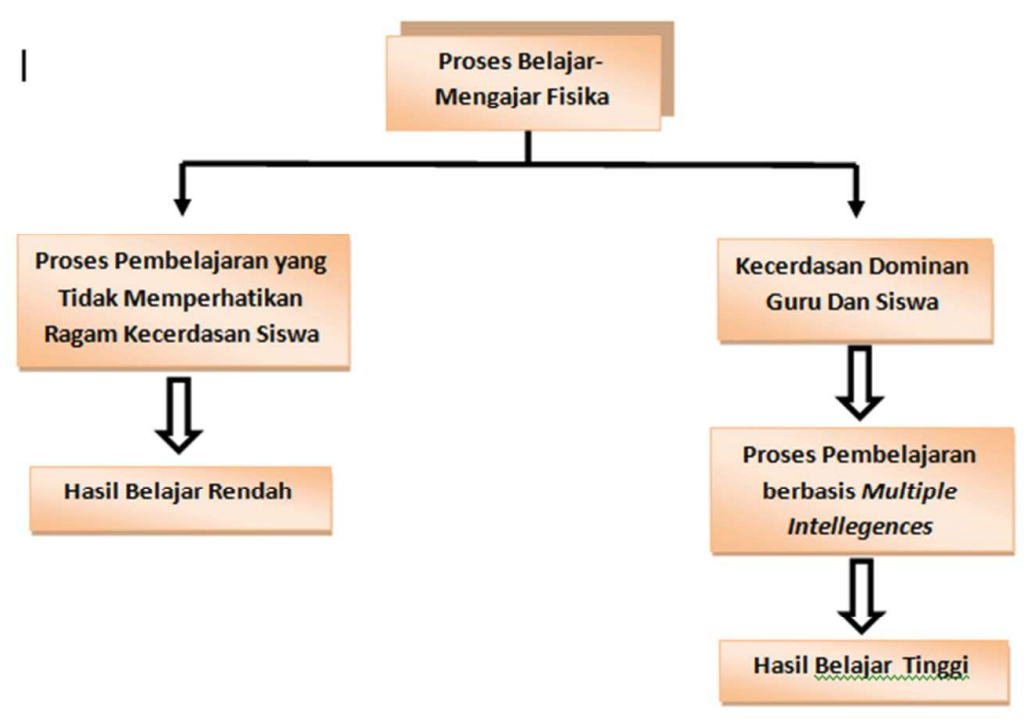

Gambar 1. Bagan Kerangka Pikir

\subsection{Hipotesis Penelitian}

Berdasarkan tinjauan pustaka dan kerangka berfikir di atas, maka dirumuskan hipotesis penelitian sebagai berikut :

"Terdapat peningkatan hasil belajar peserta didik yang signifikan setelah diterapkan Teori Multiple Intelligences dalam pembelajaran fisika“.

"Hasil belajar peserta didik yang berkecerdasan dominan yang sama dengan kecerdasan dominan guru meningkat secara signifikan setelah diterapkan Teori Multiple Intelligences dalam pembelajaran fisika“".

"Hasil belajar fisika peserta didik yang berkecerdasan dominan yang tidak sama dengan kecerdasan dominan guru meningkat secara signifikan setelah diterapkan Teori Multiple Intelligences dalam pembelajaran fisika “.

2.3. Desain Penelitian

Desain penelitian yang digunakan adalah One Group Pre Test-Post Test Design yang merupakan bentuk dari Pre Experimental Design (Arikunto, 2006). Desain penelitiannya sebagai berikut:

Keterangan:

$$
\mathrm{O}_{1} \times \mathrm{O}_{2}
$$

$\mathbf{O}_{1}$ merupakan tes awal yang berisi soal pilihan ganda sesuai dengan materi yang diajarkan pengajar sekolah tersebut sebelumnya. (X) merupakan perlakuan yaitu berupa pembelajaran fisika melalui Pendekatan pembelajaran berbasis teori Multiple Intelligences. $\mathbf{O}_{2}$ adalah tes akhir yaitu berupa soal pilihan ganda untuk menentukan perbedaan hasil tes antara pembelajaran fisika melalui Pendekatan pembelajaran berbasis teori Multiple Intelligences maupun pembelajaran fisika dengan metode pembelajaran yang digunakan sebelumnya.

Proses penerapan teori Multiple Intellegences dalam sebuah strategi pembelajaran di kelas, dimulai dengan langkah awal yaitu mengetahui jenis kecerdasan dominan yang dimiliki oleh pengajar kemudian mengetahui jenis-jenis kecerdasan dominan yang dimiliki oleh masing-masing peserta didik. Langkah berikutnya yaitu membagi peserta didik ke dalam beberapa kelompok berdasarkan kecerdasannya masing-masing. Perlakuan yang digunakan berupa teknik mengajar yang disesuaikan dengan kecerdasan dominan pengajar dalam memberikan pembelajaran. Setiap kelompok baik kelompok yang jenis kecerdasan dominannya sama ataupun berbeda dengan jenis kecerdasan pengajarnya mengikuti teknik mengajar yang digunakan oleh pengajar dengan tetap memberikan kebebasan pada setiap kelompok untuk menuangkan ide-idenya.

Model pembelajaran yang penulis anggap cocok dan dapat digunakan yaitu pembelajaran langsung saat menyampaikan informasi dan pembelajaran berbasis masalah (Problem Based 
Intruction) saat presentasi karena dengan model pembelajaran ini, masing-masing peserta didik diberi masalah kemudian setiap peserta didik dapat memecahkan permasalahan tersebut dengan gaya belajar yang sesuai dengan jenis kecerdasannya masing-masing serta dapat mengahasilkan suatu karya berdasarkan jenis kecerdasan yang ada. Nantinya karya mereka akan dipresentasikan di depan kelas.

2.4. Defenisi Operasional Variabel

Pendekatan pembelajaran yang berbasis Teori Multiple Intelligences dalam penelitian ini dapat diartikan sebagai suatu pendekatan pembelajaran yang digunakan oleh pengajar di kelas yang menerapkan Teori Multiple Intelligences dalam pembelajaran fisika yaitu dengan membagi peserta didik ke dalam beberapa kelompok berdasarkan jenis intelegensi dominannya, kemudian pengajar mengajar dengan teknik mengajar yang sesuai dengan kecerdasan dominan yang dimiliki oleh pengajar yaitu kecerdasan visual. Hasil belajar adalah skor total yang diperoleh peserta didik dalam aspek kognitif pada pembelajaran fisika melalui penerapan Teori Multiple Intelligences.

\subsection{Teknik Pengumpulan Data}

Data dalam penelitian ini diperoleh dengan cara pemberian tes hasil belajar dalam bentuk tes pilihan berganda yang telah valid kepada peserta didik sebagai sampel. Tes tersebut diberikan sebelum (pretest) dan setelah (posttest) pembelajaran berlangsung.

\subsection{Teknik Analisis Data}

Dalam penelitian ini data yang diperoleh dianalisis dengan menggunakan dua macam statistik yaitu statistik deferensial dan statistik inferensial yang meliputi uji normalitas, uji hipotesis, serta uji peningkatan. Uji normalitas data dimaksudkan apakah data-data yang digunakan terdistribusi normal atau tidak. Untuk pengujian tersebut digunakan rumus Chi kuadrat yang dirumuskan sebagai berikut (Sudjana, 1992) :

$$
\begin{aligned}
& x^{2}=\sum_{i=1}^{k}\left[\frac{(O i-E i)^{2}}{E_{i}}\right] \ldots \ldots \ldots \ldots \ldots \ldots \ldots \ldots \ldots \ldots \\
& \text { Dimana: } \\
& \mathrm{x}^{2} \quad=\text { Nilai chi-kuadrat } \\
& \mathrm{k} \quad=\text { Banyaknya kelas interval } \\
& \mathrm{O}_{\mathrm{i}} \quad \text { = Frekuensi pengamatan } \\
& \mathrm{E}_{\mathrm{i}} \quad=\text { Frekuensi yang diharapkan }
\end{aligned}
$$

Data yang berdistribusi normal selanjutnya akan melewati tahap pengujian hipotesis yang menggunakan uji statistik parametrik yaitu uji t. Dengan rumus sebagai berikut (Arikunto, 2006),

$$
\begin{aligned}
& t=\frac{M d}{\sqrt{\frac{\sum x^{2} d}{N(N-1)}}} \\
& \text { Dimana: } \\
& t=\text { harga } \mathrm{t} \\
& M d \quad=\text { mean dari perbedaan pretest } \\
& \text { dengan posttets } \\
& x d \quad=\text { deviasi masing }- \text { masing } \\
& \text { subjek }(\mathrm{d}-\mathrm{Md}) \\
& \sum_{N} x^{2} d=\text { jumlah kuadrat deviasi } \\
& N \quad=\text { jumlah subjek pada sampel } \\
& d b \quad=\mathrm{N}-1
\end{aligned}
$$

Peningkatan yang terjadi sebelum dan sesudah pembelajaran dihitung dengan rumus gain ternormalisasi (N-Gain) sebagai berikut (Meltzer, 2002):

$$
g=\frac{S_{\text {post }}-S_{\text {pre }}}{S_{\text {maks }}-S_{\text {pre }}}
$$

Dimana:

$\mathrm{S}_{\mathrm{pre}} \quad=$ skor rata-rata pada tes awal

$\mathrm{S}_{\text {post }}=$ skor rata-rata pada tes akhir

$\mathrm{S}_{\text {maks }}=$ skor rata-rata maksimum yang mungkin dicapai

Kriteria tingkat $N$-gain adalah sebagai berikut 
Tabel 1 kategori tingkat $N$-gain

\begin{tabular}{|l|l|}
\hline Batasan & Kategori \\
\hline $\mathrm{g}>0,7$ & Tinggi \\
\hline $0,3 \leq \mathrm{g} \leq 0,7$ & Sedang \\
\hline $\mathrm{g}<0,3$ & Rendah \\
\hline
\end{tabular}

(R. R. Hake. 1999)

\section{HASIL DAN PEMBAHASAN}

Berikut ini dikemukakan hasil deskriptif pencapaian hasil belajar peserta didik yang diterapkan Teori Multiple Intelligences dalam pembelajaran fisika.

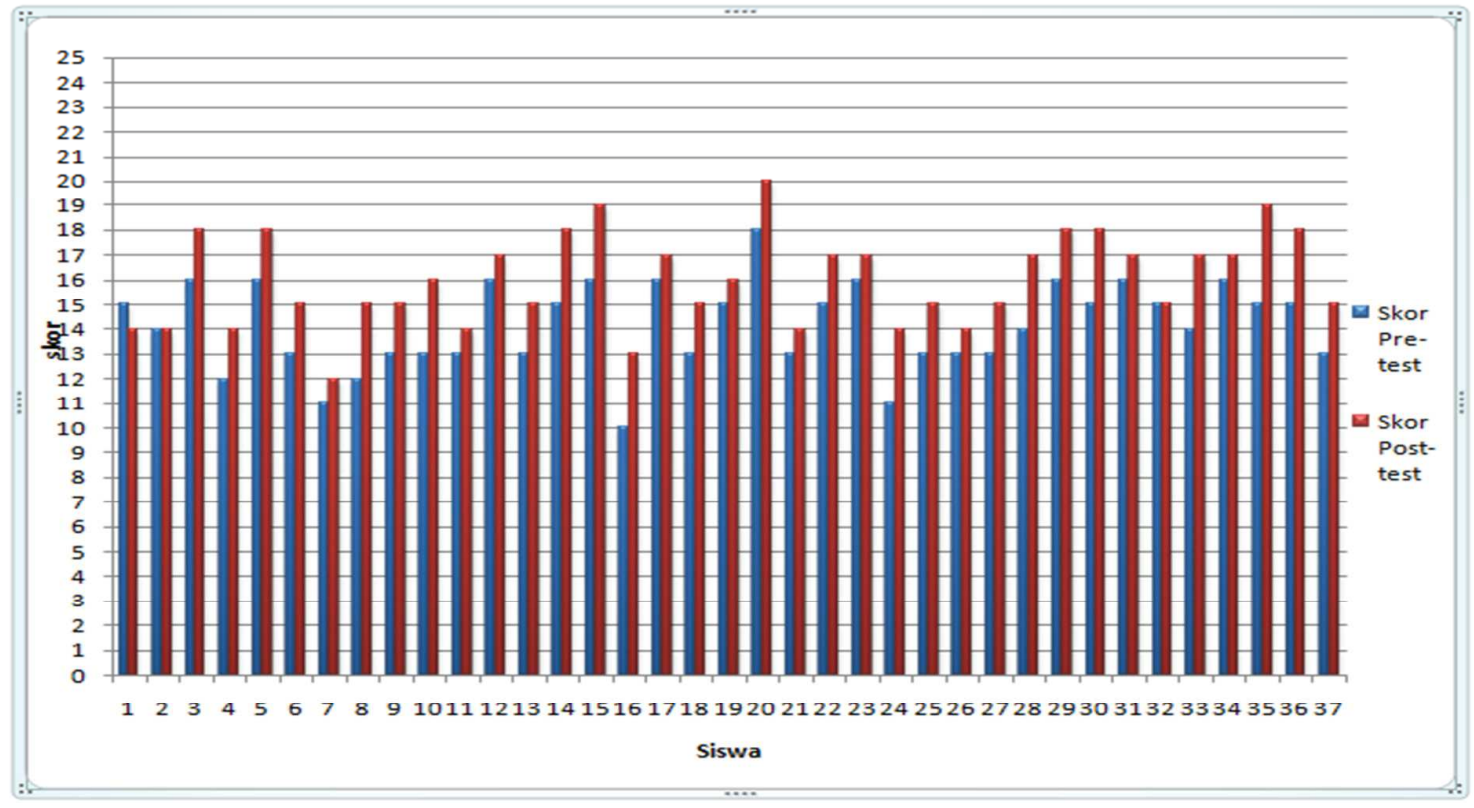

Gambar 2: Distribusi frekuensi peningkatan skor hasil belajar peserta didik pada pretest dan posttest.

Untuk diagram batang yang berwarna biru merupakan skor untuk pretest dan untuk diagram berwarna merah skor untuk posttest, dimana terlihat bahwa hampir semua batang merah lebih tinggi daripada batang warna biru. Hal ini berberarti bahwa terdapat peningkatan hasil belajar peserta didik setelah diajar menggunakan pendekatan pembelajaran berbasis teori Multiple Intelligences.

Dari hasil pengujian peningkatan (uji gain) pun diperoleh data bahwa hasil belajar peserta didik yang memiliki kecerdasan dominan yang sama dengan pengajar (kelompok visual) meningkat dengan nilai gain $=0.3$ yakni berada pada kategori "sedang" dan hasil belajar peserta didik yang memiliki kecerdasan dominan yang berbeda dengan pengajar (kelompok non visual) juga ikut meningkat dengan nilai gain $=0.2$ yakni berada pada kategori "rendah".

Peningkatan hasil belajar kelompok visual lebih tinggi dibanding kelompok non visual, hal ini disebabkan karena teknik mengajar yang digunakan dalam proses pembelajaran sesuai dengan kecerdasan dominan yang kelompok ini miliki yaitu kecerdasan dominan dimana pengajar menyampaikan materi disertai dengan gambar dan animasi yang berhubungan dengan materi yang disampaikan sedangkan bagi kelompok non visual teknik ini tidak sesuai dengan kecerdasan dominan mereka meskipun ternyata hasil belajar mereka ikut meningkat pula. Hal ini disebabkan karena para peserta didik di kelompok non visual sebenarnya juga memiliki kecerdasan visual meskipun bukan merupakan kecerdasan dominannya, minat mereka ikut terangsang untuk belajar fisika karena menggunakan teknik mengajar yang berbeda dari sebelumnya selain itu dalam proses pembelajaran, pengajar juga masih tetap memberikan kesempatan yang luas pada peserta didik untuk menuangkan ide-ide mereka sesuai kecerdasan dominanan yang mereka miliki masing-masing. 
Merunut dari pemaparan di atas dapat dikatakan bahwa pendekatan pembelajaran berbasis multiple intelligences dapat digunakan dalam proses pembelajaran untuk meningkatkan hasil belajar peserta didik. Karena diketahui bahwa setiap peserta didik tidak sama dalam menangkap pelajaran, setiap peserta didik memiliki kecerdasan dominannya masing-masing. Olehnya itu pengajar dituntut untuk pandai menerapkan suatu teknik mengajar yang sesuai dengan kecerdasan para peserta didiknya dan kecerdasan dominan pengajar itu sendiri.

Para peserta didik yang dulunya menganggap dirinya tidak tertarik terhadap mata pelajaran fisika karena merasa kurang pandai dalam hal perhitungan dan menghapal rumus mulai menaruh perhatian pada mata pelajaran ini, mereka menemukan cara baru yang sesuai dengan kecerdsan dominannya untuk memahami fisika. Namun tidak bisa dipungkri bahwa kekurangan-kekurangan yang terjadi pada model pembelajaran ini terjadi, yaitu pada kelompok non visual. Ada beberapa peserta didik yang tidak mengalami peningkatan hasil belajar sama sekali. Hal ini diduga disebabkan karena peserta didik tersebut tidak tertarik pada teknik mengajar bergaya visual yang diterapkan oleh pengajar.

Hasil analisis inferensial yakni pengujian hipotesis juga menunjukkan bahwa terdapat peningkatan hasil belajar pada peserta didik, baik secara umum maupun bagi peserta didik yang memiliki kecerdasan dominan visual ataupun non visual jika diajar dengan penerapan pendekatan pembelajaran berbasis teori multiple intelligences. Hal ini dapat terlihat pada pengujian hipotesis yaitu ke-tiga hipotesis penelitian diterima. Hal ini memberikan indikasi bahwa pembelajaran dengan menggunakan pendekatan pembelajaran berbasis Teori Multiple Intelligences dapat memberikan peningkatan hasil belajar yang meningkat.

\section{KESIMPULAN}

Berdasarkan hasil penelitian dan pembahasan, maka dapat disimpulkan 3 hal bahwa :

1. Hasil belajar peserta didik meningkat secara signifikan setelah diterapkan Teori Multiple Intelligences dalam pembelajaran fisika.

2. Hasil belajar fisika peserta didik kelas yang berkecerdasan dominan visual meningkat secara signifikan setelah diterapkan Teori Multiple Intelligences dalam pembelajaran fisika.

3. Hasil belajar fisika peserta didik yang berkecerdasan dominan non visual meningkat secara signifikan setelah diterapkan Teori Multiple Intelligences dalam pembelajaran fisika.

\section{DAFTAR PUSTAKA}

Arikunto, Suharsimi. 2006. Prosedur Penelitian Suatu Pendekatan Praktik. Rineka Cipta : Jakarta Chatib, Munif. 2010. Sekolahnya Manusia. Kaifa: Bandung

Hake, Richard. R. 1999. Analyzing Change/Gain Scores. Department of Physics, Indiana University

Meltzer, David. E. 2002. The relationship between mathematics preparation and conceptual learning gains in physics: a possible .hidden variable in diagnostic pretest scores. Department of Physics and Astronomy, Iowa State University

Sudjana. 2005. Metode Statistika. Tarsito : Bandung

Sugiharti, Piping. 2005. Penerapan Teori Multiple Intelligence dalam Pembelajaran Fisika. Jurnal Pendidikan Penabur : Jakarta

Uno, Hamzah B \& Kuadrat, Masri. 2009. Mengelola Kecerdasan Dalam Pembelajaran (Sebuah Konsep Pembelajaran Berbasis Kecerdasan). Bumi Aksara: Jakarta. 